\title{
Study on the Role of Real Estate Industry in the Employment of Related Industries
}

\author{
Bei Su 1, a \\ ${ }^{1}$ No. 3 Shangyuancun, Beijing Jiaotong University, Haidian District, Beijing 100044, China \\ asubei1993@163.com
}

\begin{abstract}
Keywords: real estate; sustainability; relevant industries; employment; driving effect
Abstract. Nowadays, real estate industry is fast growing in our country and it has an important effect on the related industries. Based on the relationship between real estate industry and output of other industries, this paper adopted empirical analysis model to further explore the correlation between the investment of real estate and employment of related industries in recent years.
\end{abstract}

\section{Introduction}

Entering the 21st century, real estate industry is fast growing in our country. The investment of real estate in China reached 95979 billion in 2015, nearly 9.5 times in 2003. Also because real estate has a long market chain and many related industries, many scholars were concerned about the relationship between real estate and related industries. Take "The Driving Effects on Real Estate to the Correlative Industries” authored by Wang Guojun \&Liu Shuixing for example, the paper adopted Input-output model to analyze the forward and backward quantity correlation between real estate and other industries for China and four member countries of OECD, by International and regional Comparative analysis, as to find the inner structure and mutual affections between Real Estate and other Industries, to provide quantity criterions for the harmonized development of real estate and national economy . However, the relevant research paper was published much earlier, and most of them referred to the direct influence of real estate industry on the output value of related industries only, not related to the employment of related industries.

Based on the relationship between real estate industry and output of other industries, this paper expanded the range from a single output value to the employment of the related industries, adopting the updated data, to further explore the correlation between real estate and employment of related industries in recent years, and proposed policy recommendations.

\section{Data Description}

1. According to "China Statistical Yearbook 2014", the paper adopted the indicator named " investment of real estate development " to reflect the development of real estate.

2. According to the designation on the real estate industry in the previous studies, and the statistical indicators of related industries employment in "China Statistical Yearbook 2014 ", the paper adopted construction industry employment, real estate industry employment, mining industry employment, financial industry employment and manufacturing industry employment five indicators to reflect the employment situation in the related industries of the real estate industry.

3. Due to China's real estate industry has developed much faster in twenty-first Century, the paper selected related data in 2003-2014, which can fit the needs of current stage of development. The specific data are shown below in table 1: 
Table 1 The investment of real estate development and employment of related industrial in China

\begin{tabular}{|l|r|r|r|r|r|r|}
\hline & $\begin{array}{l}\text { Investment } \\
\text { of real estate } \\
\text { development } \\
\text { (Ten billion } \\
\text { yuan) }\end{array}$ & $\begin{array}{l}\text { lonstruction } \\
\text { industry } \\
\text { employment } \\
\text { ten } \\
\text { thousand } \\
\text { people) }\end{array}$ & $\begin{array}{l}\text { Real estate } \\
\text { industry } \\
\text { employment } \\
\text { ten } \\
\text { thousand } \\
\text { people })\end{array}$ & $\begin{array}{l}\text { Mining } \\
\text { industry } \\
\text { employment } \\
\text { ten } \\
\text { thousand } \\
\text { people) }\end{array}$ & $\begin{array}{l}\text { Financial } \\
\text { industry } \\
\text { employment } \\
\text { ten } \\
\text { thousand } \\
\text { people })\end{array}$ & $\begin{array}{l}\text { Manufacturing } \\
\text { industry } \\
\text { employment } \\
\text { (ten } \\
\text { thousand } \\
\text { people }\end{array}$ \\
\hline 2003 & 833.7 & 120.2 & 101.538 & 488.3 & 353.3 & 2980.5 \\
\hline 2004 & 841.0 & 133.4 & 131.5825 & 500.7 & 356.0 & 3050.8 \\
\hline 2005 & 926.6 & 146.5 & 159.0925 & 509.2 & 359.3 & 3210.9 \\
\hline 2006 & 988.7 & 153.9 & 194.2292 & 529.7 & 367.4 & 3351.6 \\
\hline 2007 & 1050.8 & 166.5 & 252.8884 & 535.0 & 389.7 & 3465.4 \\
\hline 2008 & 1072.6 & 172.7 & 312.0319 & 540.4 & 417.6 & 3434.3 \\
\hline 2009 & 1177.5 & 190.9 & 362.4181 & 553.7 & 449.0 & 3491.9 \\
\hline 2010 & 1267.5 & 211.6 & 482.592 & 562.0 & 470.1 & 3637.2 \\
\hline 2011 & 1724.8 & 248.6 & 617.9689 & 611.6 & 505.3 & 4088.3 \\
\hline 2012 & 2010.3 & 273.7 & 718.0379 & 631.0 & 527.8 & 4262.2 \\
\hline 2013 & 2921.9 & 373.7 & 860.1338 & 636.5 & 537.9 & 5257.9 \\
\hline 2014 & 2921.2 & 402.2 & 950.3561 & 596.5 & 566.3 & 5243.1 \\
\hline
\end{tabular}

\section{Quantitative Analysis}

In order to further study the relationship between investment of real estate development and the specific employment of each related industry, the paper used Eviews software to make scatter plot. In consideration of eliminating the influence of different variance, the paper adopted the method for processing all data by taking logarithm, using LNTZ, LNFDC, LNCK, LNJR, LNJZH, LNZHZ representing the investment of real estate development, real estate employment, employment in the mining industry, financial industry employment, employment in the construction industry and the number of manufacturing employment. From the scatter plot, it could be found that the amount of investment in real estate development has a certain positive correlation to the employment of related industries.

In order to establish the co integration relationship between the real estate development investment and related industry, first of all, the paper made ADF stability test on each of the variables. The original hypothesis $\mathrm{H} 0: \mathrm{P}=1$ (there is a unit root in the sequence), the alternative hypothesis $\mathrm{H} 1$ : $\mathrm{P} \neq 1$ (it does not exist unit root in the sequence).

$$
\mathrm{Z}_{\mathrm{t}}-\mathrm{Z}_{\mathrm{t}-1}=(\rho-1) \mathrm{Z}_{\mathrm{t}-1}+\beta_{0}+\beta_{1} \mathrm{t}+\mathrm{v}_{\mathrm{t}}
$$

After several tests, the paper adopted ADF test of two order difference level on each log data. Results are shown in the following table 2: ADF test t value of real estate investment is -3.989378, less than Test critical values of $5 \%$ level, rejecting the original hypothesis (there is no unit root), that is, LNTZ is the two order single integration at the $5 \%$ confidence level; ADF test t value of mining employment is -2.838419 , less than Test critical values of $10 \%$ level, rejecting the original hypothesis(there is no unit root), that is, LNCK is the two order single integration at the $10 \%$ confidence level; ADF test $t$ value of real estate employment is -8.695886, less than Test critical values of $1 \%$ level, rejecting the original hypothesis(there is no unit root), LNFDC is the two order single integration at the $1 \%$ confidence level; ADF test $t$ value of financial industry employment is -2.88195 , less than Test critical values of $10 \%$ level, rejecting the original hypothesis(there is no unit root), LNJR is the two order single integration at the $10 \%$ confidence level; ADF test $t$ value of construction industry employment is -2. 952018, less than Test critical values of $10 \%$ level, rejecting 
the original hypothesis (there is no unit root), LNJJZH is the two order single integration at the 10\% confidence level; ADF test $t$ value of manufacturing industry employment is -1.773533 , greater than Test critical values of $10 \%$ level, accepting the original hypothesis (there is a unit root), that is, LNJR is not stable.

Table 2 Results of ADF test

\begin{tabular}{llllll}
$\begin{array}{l}\text { LNTZ } \\
\text { t-Statistic }\end{array}$ & $\begin{array}{c}\text { LNCK } \\
\text { t-Statistic }\end{array}$ & $\begin{array}{c}\text { LNFDC } \\
\text { t-Statistic }\end{array}$ & $\begin{array}{c}\text { LNJR } \\
\text { t-Statistic }\end{array}$ & $\begin{array}{c}\text { LNJZH } \\
\text { t-Statistic }\end{array}$ & $\begin{array}{c}\text { LNZHZ } \\
\text { t-Statistic }\end{array}$ \\
\hline \hline & & & & & \\
-3.989378 & -2.838419 & -8.695886 & -2.88195 & -2.952018 & -1.773533 \\
\hline
\end{tabular}

$\begin{array}{lccccccc}\text { Test } & & & & & & \\ \text { critical } & & & & & & & \\ \text { values: } & 1 \% \text { level } & -4.582648 & -4.420595 & -4.420595 & -4.420595 & -4.803492 & -4.803492 \\ & 5 \% \text { level } & -3.320969 & -3.259808 & -3.259808 & -3.259808 & -3.403313 & -3.403313 \\ & 10 \% \text { level } & -2.801384 & -2.771129 & -2.771129 & -2.771129 & -2.841819 & -2.841819\end{array}$

According to ADF test results, in addition to the employment of manufacturing industries, other related industries are able to establish a co integration relationship with real estate investment. Put LNTZ as the independent variables, respectively, with LNJZH, LNJR, LNCK, LNFDC as the dependent variable to establish the co integration model. Taking LNJR as an example, the regression results were analyzed:

$$
\begin{aligned}
& \text { LNJR=4.739395+0.229797LNTZ } \\
& \mathrm{t}=(61.77053) \\
& \mathrm{R} 2=0.968577
\end{aligned}
$$

Through the calculation of residual sequence of this model, $\mathrm{P}$ value of ADF test is $0.0107<0.05$, showing the unit root test is rejected under $5 \%$ of the significant level, and the residual term is stable. Therefore, the financial industry employment has the co integration relationship with real estate development investment, indicating that there is a long-term stable equilibrium relationship between the two variables, and real estate development investment for each $1 \%$ change, will cause the financial employment changes in the number of $0.23 \%$.

Similarly, we can find that construction industry employment, mining industry employment and real estate industry employment respectively has a long-term stable equilibrium relationship with the investment of real estate development. And real estate development investment amounts for each 1\% change, respectively, causing construction industry employment increases $0.56 \%$, mining employment increases $0.11 \%$ and real estate employment increases $0.50 \%$. Thus, the investment of real estate development has a certain role in the employment of related industries. Among them, the real estate investment has a greater impact on the construction industry employment and real estate industry employment than any other.

According to the co integration relationship between the employment of related industries and investment of real estate development, the results of the Grainger causality test between variables are shown in the following table 3: real estate development investment is the Grainger reason of financial employment only. Thus, real estate investment is one of the important reasons for the number of financial industry employment. And as for other related industries, the number of employment is not only determined by the amount of real estate investment, also some other decisive reasons. 
Table 3 The Granger Causality Tests

\begin{tabular}{|c|c|c|c|}
\hline Null Hypothesis: & Obs & F-Statistic & Prob. \\
\hline LNJZH does not Granger Cause LNTZ & 10 & 1.92876 & 0.2394 \\
\hline LNTZ does not Granger Cause LNJZH & & 0.71760 & 0.5321 \\
\hline LNTZ does not Granger Cause LNJR & 10 & 7.27349 & 0.0331 \\
\hline LNJR does not Granger Cause LNTZ & & 0.38967 & 0.6962 \\
\hline LNCK does not Granger Cause LNTZ & 10 & 1.13290 & 0.3928 \\
\hline LNTZ does not Granger Cause LNCK & & 2.58318 & 0.1696 \\
\hline LNTZ does not Granger Cause LNFDC & 10 & 0.16140 & 0.8552 \\
\hline LNFDC does not Granger Cause LNTZ & & 1.31223 & 0.3483 \\
\hline
\end{tabular}

\section{Conclusion}

According to econometric analysis, there is a long-term stable equilibrium relationship between real estate investment and employment of related industries. And the investment of real estate development amounts for each 1\% change, respectively, will cause construction employment increases $0.56 \%$, financial employment increases $0.23 \%$, mining employment increases $0.11 \%$, real estate employment increases $0.50 \%$. In addition, the real estate investment is the Grainger cause of financial industry employment, the increase in real estate investment has a positive role in promoting the employment of the financial sector.

\section{References}

[1] WANG Guojun, LIU Shuixing: The Driving Effects on Real Estate to the Correlative Industries .Trans Economic Research Journal. (2004), p. 39

[2] XU Xianchun, JIA Hai: On the Role Played by Real Estate in the Growth of China's National Economy, Social Sciences in China. (2015), p. 84 